\title{
The Effect of Changes on Management of Generation Y Employees: A Study Case of Poland
}

\author{
Izabela Bednarska-Wnuk (Ph.D) \\ Faculty of Management, University of Łodź, ul. Matejki 22/26, Poland
}

\section{Doi:10.5901/mjss.2014.v5n21p141}

\begin{abstract}
The generation that operates in the labor market nowadays is the subject of scientific inquiry for some time. This is the generation $Y$. Undoubtedly, their functioning was influenced by a number of changes that shaped their values and attitudes towards work and determined their system of needs and aspirations. These include mainly changes related to socio-economic transitions, the sphere of employment and the changes arising from the nature and essence of work and the paradigm shift regarding norms and values. The generation $Y$ is most often considered through the prism of homogeneous characteristics, without including the socio-cultural context. Taking this into account, the paper focuses on the generation $Y$ that comes from Poland and it attempts to answer the question of actions that should be taken in the area of selection, motivation and promotion of people representing this generation. In view of the above aim, firstly, the most important symptomatic changes affecting this generation were identified, then an overview of Polish research on expectations of Gen $Y$ of work was presented and, finally, conclusions relevant for the management of these individuals were formulated.
\end{abstract}

Keywords: human resources management, generation Y, Poland

\section{Introduction}

The changes in the environment undoubtedly affect the functioning of Gen $\mathrm{Y}$ in the organizational space. The review of foreign literature suggests that this generation "wants to have it all", "wants to have it now", they want a good job, benefits, a work-life balance and an interesting and challenging job [Ng, Schweitzer, Lyons 2010, p. 282]. This generation is born after 1982 [Shragay, Tziner, 2011, p. 143], however, the literature gives different time ranges [Vinke, Loredana, Nicolae 2012, p. 751]. It is called most often a Millenium generation. This generation is different from the previous one in the range of accepted values in both private and professional life. A specific generation $Y$ seems to be the one coming from Poland as they grew up in an independent country, in the new economic system - capitalism and in the era of digital technologies, having unrestricted access to all material resources. Their values and attitudes are also a necessary element of knowledge about them, especially in the context of human resource management in the organization and are a key challenge for HR managers. Proven and effective methods applied to the previous generation are not effective anymore in generation $Y$. Therefore, it is important to know which actions should be taken in the area of selection, motivation and promotion of Gen Y, coming from Poland. Taking into account this aim, firstly, the most important symptomatic changes affecting this generation were identified, then an overview of Polish research on expectations of Gen $Y$ of work was presented and, finally, conclusions relevant for the management of these individuals were formulated.

\section{Changes Affecting the Current Generation $Y$}

Nowadays, we live in times when changes are the primary category of description of both organizations and individuals. They interact with all elements of the environment and the subsystems of organization and, in particular, its participants. Although the pace of these changes is non-linear and in some areas or periods they run slower and in other faster, surely they have a definite influence on the phenomena taking place in the organization. Certainly, operating in such an area requires knowledge of symptomatic changes allowing for understanding the attitudes and behavior of the modern workforce and, above all, the generation $\mathrm{Y}$. These are primarily changes related to socio-economic transitions and the sphere of employment, arising from the nature and essence of work and a change in the paradigm of norms and values. Undoubtedly, all these changes are the aftermath of the transition from a centrally planned economy to a capitalist economy and trends related to the increasing instability of the environment in Poland. 


\subsection{Changes Related to the Socio-Economic Transitions}

Discussing the social and economic changes on the Polish ground, the political transformation, whose consequences are assessed to this day, should be mentioned. It contributed to the release of the market mechanism and modernization of the economy, expressed by increasing the efficiency and improving the branch structure and a radical change in the ownership structure (Hanusik, Łangowska-Szczęśniak 2005, p. 27). From the perspective of 25 years of existence of the new economic system, it may be noted that it undoubtedly contributed to economic growth in Poland. Although in 2003 the unemployment rate was about 20\%, Poland's accession to the European Union helped the country in improving macroeconomic indicators (GDP growth and reducing unemployment), and initiated a number of investments. At the same time, the unfavorable situation is noticed among young people. Unemployment among young people in Poland has become the most important social issue and a challenge for the Polish economy since the early nineties. In addition to economic and psychosocial effects, they experience such processes as: delay in starting their adult working life, hindering acquiring professional qualifications and impeding the process of economic empowerment through work [Kopertyńska 2009, p. 76]. At the end of April 2014, as reported by Eurostat, in Poland unemployment among people under 25 years of age is $24.6 \%$ [Eurostat]. In addition, the social stratification is observed in Poland which, according to the Gini Index showing income inequality of a society from the early 90 s to 2009 , is growing steadily. In contrast, in 20092013, this ratio decreased from 0.313 to 0.299 [Czapiński, Panek 2013, p. 397].

Undoubtedly, the socio-economic transformation in Poland was also influenced by the processes of globalization, which in the twenty-first century have a huge impact on all areas of socio-economic life. They shape and condition the functioning of modern organizations and influence the execution of the role of the modern individual. Globalization allows for faster transfer of technology, it enables the implementation of many investments by foreign capital inflows, contributing to the development of the economy and increasing the welfare of society. A manifestation of globalization is the internationalization and multinationalization of many organizations. Although the processes of globalization have their opponents, their advantages are mainly: increased range of mobility enabling people to find work all around the world, new organizational capabilities, working in a multicultural environment, employment opportunities based on new forms of work, faster technological progress, rapid access to information and easiness to establish social and professional relationships due to the development of social infrastructure.

Globalization processes undoubtedly influenced generation $Y$ because they grew up in the period in which differentiated goods began to be widely available, a consumerist model of life became popular and Poland began to open up to trends, fashion and events flowing from the West [Mikoś, 2011].

When discussing the social changes, the technological development that have changed the way of functioning of the younger generation should not be omitted. They can easily use all technological devices while shaping not only their work environment but also their own social space. The technological progress in this area resulted in this generation having contacts with other representatives of this generation around the world through the operation of multiple social networking sites and creating a virtual community, among others. There is a reason for it gaining the name of the Search Generation, the Next Generation, the Net Generation, the Digital natives or the dot.com Generation [Van den Bergh and Behrer, 2011, p. 7].

\subsection{Changes Related to the Employment Sphere}

The next area influencing organizational behavior of the generation $Y$ are the changes associated with the employment sphere. The socio-economic changes in Poland were followed by the changes in the sphere of employment. More and more often, Polish organizations began to employ workers based on flexible forms of employment after the transition period. This is the result of significant labor costs associated with permanent employment service. As a consequence, many organizations are striving to reduce the share of permanent employees and increase the participation of peripheral employees in the general structure of employment. A characteristic feature of these employees are powers which are quite easy to get on the external labor market or are unique, but to keep an employer with such powers within permanent forms of employment would be very costly to the organization [Bohdziewicz 2008 p. 107-108]. Flexible work arrangements are also an important element of professional activation in the labor market and the increased interest in them is also noticed in the European Union. There are a response to high unemployment, labor market segmentation processes and the growing costs of running the companies. As the results of the European Business Studies from 2009 show, Poland does not differ from the European average in the use of part-time contracts in enterprises. In the EU, 67\% of companies employed at least one part-time employee. In Poland, however, this percentage amounted to about $66 \%$ [Berezka 2012, p. 102-103]. 
This form of employment is particularly attractive to young people as it allows for gaining first professional experience, combining studies with work and it is an opportunity to obtain permanent employment. Undoubtedly, the problems include: lack of vital stabilization, the agreement may be concluded for a very short period of time, and even renewed daily. A statutory limitation is only the total duration of the contract with one employer - up to 18 months in a period of three years. No additional protection applies to employment in the case of a woman who became pregnant. It is quite the opposite in the case of a contract of employment for a specified period [Pańków 2012, p. 31]. All this means that young people become independent very late and postpone the decision to start a family. In Poland, the discussion on this kind of form of employment is conducted from time to time, but it is still very popular and used.

\subsection{Changes in the Norms and Values}

Significant changes in the functioning of modern workers, in particular, belonging to Gen $\mathrm{Y}$ are also associated with the plane of norms and values, becoming a determinant of behavior for individuals and directly shaping the space in which they operate. What once was the stability and certainty in the professional sphere, for instance, cognitive scripts which were implemented in the context in which they were created, today has changed dramatically. According to Januszkiewicz, constraints of space, time and place are beginning to play a smaller role because indirect factors have a greater influence on the generation's work ethic. This means freedom of choice and freedom to design professional goals the individual wants to achieve and the ways to do so. [Januszkiewicz 2014, p. 120]. Today we are dealing with a state of uncertainty, especially in the construction of one's self. The changing organizational value system determines the quality of social relationships. Man joining the organization must be aware of the fact that these relationships will be of a temporary nature and social ties will not be the same as in the traditional terms of employment. The modern worker from an individual who is loyal and tied to the organization becomes an autonomous and independent entity responsible for their own career trajectories and professional development as well as they considers the choices of employment in terms of the benefits.

\subsection{Changes Resulting from the Nature and Essence of Work}

Along with the processes taking place in the labor market, the nature and essence of the work are changing. Nowadays, they do not apply to a specific set of operations or tasks that the employee performed during the statutorily specified time in the past, but to participation in projects, sometimes several at the same time, at the crossroads of different cultures, performed in different time zones [Kołodziejczak 2012 p. 190]. Changes in the organization result in the following characterization of the contemporary work: a greater focus is put on more diverse activities, there is more work and it has to be done in less time. Thus, there is a general tendency for "packing" more of the items, processes and behaviors in the same time. This is the so-called "compaction of work" [Adamiec 2007, p. 197]. This phenomenon will be intensified because nowadays more and more is required of the employee in respect of the implementation, execution and the nature of work. It is not a single monogram, but it takes the form of mosaics, whose all the elements, even though they are different, they form a homogeneous whole. Additionally, the pace of work is much faster than it was in traditional organizations. On the grounds of the maximization of the cost in the organization with simultaneous increasing standards of performance, carrying out the work as soon as possible is required from today's employees. Changes in the nature of work undoubtedly affect the process of evaluating all components of quality of life and contribute to any dysfunctional phenomena in the operation of the individual, such as burnout or stress. Changes in the nature and content of work imprint their mark especially on young people who appreciate the balance between work and private life and are not willing to make sacrifices for the organization in the form of working overtime. It is also difficult to find young people who will work till morning, wanting to show their skills. Therefore, this generation finds it hard to perform monotypic works and work under pressure. They prefer positions related to creativity and innovation, not interfering with work-life balance.

\section{Expectations of Polish Gen Y of Work - A Review of Selected Studies}

All of the changes described undoubtedly affect the functioning of Gen $Y$ in the organization. Therefore, it becomes important to know what expectations Gen $Y$ has in the first place to be able to formulate recommendations for organizational practice in the area of human resource management. These are illustrated through various study results carried out in Polish territory.

According to research conducted in the Polish territory among representatives of Gen $Y$ in the period of MarchJune 2013 by Kopertyńska and Kmiotek, work is not the most important value for them. They value family, relationships 
with friends, the possibility of pursuing passions and interests, free time and opportunity for professional development more. The working conditions expected by generation $Y$ are: a good atmosphere at work, clarity in communicating the objectives and tasks and job stability, resulting from the possession of an employment contract for an indefinite period. In addition, within the professional development, they expect from employers the creation of favorable conditions in this area, opportunities to participate in training, independence in performing the tasks, the organization of work allowing for the sharing of knowledge, gaining experience and learning, as well as conditions conducive to demonstrate their knowledge and skills. In addition, one of their characteristics is the tendency to give up their jobs when they are not satisfied with it or when the wages and working conditions are not suitable [Kopertyńska and Kmiotek 2014, p. 343-352].

In contrast, a study performed among Gen Y by Smolbik-Jęczmień in 2010 and 2011 indicates that the majority of the generation identify career primarily with vertical promotion and a desire to occupy more senior positions in the organization, and over half of them expected a high position of material safety and stabilization at work. Besides, they present a slightly different approach to career focusing primarily on the continuous improvement of their competence as a necessary condition for a career, then on the possibility of self-actualization and a sense of fulfillment through work, professional achievements and satisfaction at work [Smolbik-Jęczmień 2013, p. 89-98].

In turn, the main conclusions of a study on the subject of Gen Y carried out by Cewińska, Striker and Wojtaszczyk in 2007 are [Cewińska, Striker and Wojtaszczyk 2009, p.118-134]:

- a dream job for Gen $Y$ is primarily the one that, inter alia, involves one's interests, guarantees regular monthly income, provides peace, stability and certainty, is performed using a computer, allows one to wear informal clothes, is associated with contact with people of different nationalities, gives one the opportunity to influence happenings in the organization, allows for the reconciliation of work and private life,

- $\quad$ this generation prefers working as a team to working individually,

- they are characterized by their skepticism when they hear about loyalty to the employer, a long-term commitment to the organization and building their career is not important for them,

- they pay greater attention to partnership relationships in the workplace, not just with colleagues but also with senior executives,

- although they prefer to communicate using modern technology, they also appreciate the direct contacts,

- this generation feels that they are special, they like to learn using the computer, they can perform tasks as long as they are compatible with their system of values.

The study results concerning the generation Y obtained by Stachowska in 2011 are similar. This study shows that the most important values in life are family and love. Work and money took second place. A high salary and a good atmosphere were considered the most desirable features of future work by respondents. What is important for them is also a job that provides an opportunity for professional development and personal fulfillment, a guarantee of financial stability, good conditions for the performance of tasks, and the possibility of promotion. The results confirmed the tendency of young people for occupational mobility and openness to change [Stachowska 2012, p. 33-56]. This aspect is also pointed out in the study of Bednarska-Wnuk, which shows that the younger generation has a higher propensity to change jobs taking into account their willingness to relocate and retrain treated as a natural process in the professional development of the individual. In addition, although in the vast majority the respondents declare readiness to seek work in another province or another country, they mostly do not want to take up employment in another continent. It is probably due to cultural habits of Polish society. Indeed, they consider emigrating to another country, but this country is mostly within the European Union. The respondents also believe that in order to pursue a professional career they do not have to work all their life in one organization [Bednarska-Wnuk 2012, p. 86-94].

In turn, Januszkiewicz in his study draws attention to the perception of success of generation Y. The study's results indicate that Polish young generation sees professional success as a category achieved relatively quickly and repeatedly throughout life, it is therefore, no longer the culmination of a career, but rather a term for some of its levels. Professional success is seen as an inherent feature of career and the costs of success are seen primarily in terms of its negative impact on family and social life, but not always in the workplace [Januszkiewicz 2012, p. 357].

A fragment of selected research presents the most important attitudes and values characteristic of the Polish generation. It may be noted, however, that they are typical of this generation, regardless of its geographical location, despite the functioning of young Polish people in different socio-cultural space. The presented values and attitudes towards work require a new look at the role of managing of those employees.

\section{How to Manage Generation $Y$ in the Face of Change - Challenges and Threats to the Modern Organization}

Currently, the management of generation $\mathrm{Y}$ is a big challenge for the organization. Their expectations make managers 
apply a different set of methods and techniques, and take other measures than those that were implemented to the previous generation.

Firstly, regarding recruitment, organizations should be increasingly aware of the fact that Gen $Y$ prefers direct contact with potential employers to using recruitment companies. Such contact is usually initiated during the annual Job Fairs held at universities. The generation also uses any information about employers and their advertisements put on their websites. Therefore, if organizations want to hire young people, in particular, they should attach great importance to the power of the Internet. The representatives of this generation do not take the job which does not meet their expectations regarding both the content and working conditions, nor do they take a job preventing the development of their passion.

Secondly, organizations should base the selection of employees on clear and reliable criteria, such criteria that would state the sought and actual competence and qualifications. In addition, the organization should shun discrimination against potential employees based on any criterion of selection [Cewińska, Striker and Wojtaszczyk 2009, p. 132]. It is related to the fact that young people are increasingly aware of their rights and all kinds of occurring dysfunctional behaviors.

Thirdly, incentive systems should take into account individual needs and preferences of employees. There should not be uniform for all employees, but take into account the nature and type of work performed and the individual contribution of each employee. For Gen Y, most of all, positive motivation is important. In contrast, the use of the organization's negative motivation can make the employee representing the generation $\mathrm{Y}$ easily abandon this work.

Fourthly, when hiring a young worker, the organization should think about their career path from the very beginning, depending on the individual needs. Otherwise, they may quickly abandon the current employer for such an employer who will provide promotion and development opportunities.

Fifthly, the young generation is set to perform a variety of tasks. They are good at multitasking. The organization wanting to keep employees of this generation, characterized with their ambition, the desire for self-development and high performance, should provide a job that is not monotonous and provides opportunities for competence development. In this area, the organization can use, for example, a number of methods for humanizing work, such as job rotation, job enlargement and enrichment.

Taking into account the above guidelines, Polish organizations should change, especially in the context of domination of dysfunctional management solutions in their operation. Therefore, [Cewińska, Striker and Wojtaszczyk 2009, p. 132]:

- if the organization wants to hire young and ambitious people, it should not fall behind with the payment of salaries,

- the organization should not require full availability, dedication and loyalty to the employer from all candidates,

- the organization should inform their employees about its strategy, plans and its current situation,

- the organization should not require submission to top-down decision-making from the young generation,

- the organization should not offer young people the implementation of routine and repetitive tasks that do not bring them opportunities to learn new things.

Following these rules by Polish organizations is an opportunity to keep young, talented and ambitious individuals within it. The organizations cannot forget that they should improve not only employees but also a personal function, customizable to the young generation which is now entering or operating in job market. Only such measures can ensure the organization development and certainty that young workers will remain longer in the organization. The unification of all employees in the organization and their perception through the prism of unity, regardless of their age, seniority, gender, or nationality may be fatal.

\section{Conclusions}

The analysis of the literature in this paper allowed for drawing several synthetic conclusions that respond to the questions raised in the introduction. First of all, the issue requires an in-depth empirical analysis and verifying not only the expectations of Polish Gen $Y$ but also the possibilities of Polish organizations and gaining knowledge about their organizational systems. The considerations lead to the conclusion that the characteristics of the modern generation $Y$ is generally universal, but at the same time the changes comprise an impulse to describe this category of workers. In the case of Poland, these changes are much more strongly affected this generation. This is the result of political transformation which sharpened some of the characteristics of this generation and influenced the accepted attitudes and values towards work. Therefore, Polish organizations should benefit from the experience of other countries regarding the solutions used in relations with employees from generation $Y$ and develop new standards, corresponding to the Polish 
reality and the conditions in which this generation exists now.

\section{References}

Adamiec, M. (2007). Perspektywy psychologii pracy. M. Górnik-Durose, B. Kożusznik (Eds.), Behawioryzacja działania w organizacjach i jej konsekwencje (pp.185-205), Prace Naukowe Uniwersytetu Śląskiego, Śląsk.

Bednarska-Wnuk, I. (2012). Sukces w zarządzaniu kadrami. Elastyczność w zarządzaniu kapitałem ludzkim. S.A. Witkowski\& M. Stor (Eds.), Elastyczność zawodowa w percepcji przedstawicieli pokolenia Y (pp.88-94), Publishing Wydawnictwo Uniwersytetu Ekonomicznego we Wrocławiu, Wrocław.

Berezka, A. (2012). Nietypowe formy zatrudnienia w Polsce na tle wybranych krajów unii europejskiej, Studia i Prace Wydziału Nauk Ekonomicznych i Zarządzania $\mathrm{nr}$ 28, pp.97-114.

Bohdziewicz, P. (2008). Kariery zawodowe w gospodarce opartej na wiedzy (na przykładzie grupy zawodowej informatyków), Wydawnictwo Uniwersytetu Łódzkiego, Łódź.

Cewińska, J., Striker, M., Wojtaszczyk, K. (2009). Kulturowe uwarunkowania zarządzania kapitałem ludzkim. M. Juchnowicz (Eds.), Zrozumieć pokolenie Y- wyzwanie dla zarządzania zasobami ludzkimi (pp.118-134). Publishing Oficyna Wolters Kluwer, Kraków.

Czapiński, J.\& Panek T. (2013). Social diagnosis 2013. Objective and subjective quality of life in Poland, Contemporary Economics. Quarterly of University of Finance and Management in Warsaw, Vol.7, September, Special Issue, pp.1-491.

Eurostat, [Online] Available: http://appsso.eurostat.ec.europa.eu/nui/submitViewTableAction.do (July 3, 2014).

Hanusik, K., Łangowska-Szczęśniak, U. (2005). Przemiany społeczne, ekonomiczne i organizacyjne we współczesnej gospodarce polskiej. K. Hanusik, U. Łangowska-Szcześniak, S. Sokołowska (Eds.), Uwarunkowania gospodarcze zmian struktury społecznoekonomicznej gospodarstw domowych w okresie transformacji w Polsce (pp.27-38). Publishing Uniwersytetu Opolskiego, Opole.

Januszkiewicz K. (2014). Rozwój kapitału społecznego organizacji w warunkach różnic kulturowych. A. Adamik, \& M. Nowicki (Eds.), Pokolenie Y w organizacji - pokolenie różnorodności czy unifikacji kulturowej (pp.119-128). Monografie Politechniki Łódzkiej, Łódź.

Januszkiewicz, K. (2012). Sukces zawodowy w percepcji pokolenia Y, Studia Ekonomiczne Regionu Łódzkiego. Polskie Towarzystwo Ekonomiczne Oddział w Łodzi, Łódż, pp. 351-357.

Kołodziejczak M. (2012). Zachowania ludzi w organizacji. Uwarunkowania i kierunki ewolucji. K. Januszkiewicz (Eds.), Istota i znaczenie pracy, Publishing Wydawnictwo Uniwersytetu Łódzkiego, Łódź.

Kopertyńska, M.W. (2009). Rynek pracy w Polsce w dobie integracji europejskiej i globalizacji. M. Noga \&K. Stawicka (Eds.), Sytuacja ludzi młodych na rynku pracy i jej wpływ na ich aktywność (pp.75-91). Publishing CeDeWu.pl, Warszawa.

Kopertyńska, M., W., Kmiotek K. (2014). Granice w zarządzaniu kapitałem ludzkim. P. Wachowiak, S. Winch (Eds.), Granice zmian systemów motywowania określone oczekiwaniami pracowników pokolenia Y (pp. 343-352). Publishing Szkoła Główna Handlowa w Warszawie, Warszawa.

Mikoś, A. (2011), Gen Y na rynku pracy. [Online] Available: http://hrstandard.pl/2011/11/14/gen-y-na-rynku-pracy/ (July 3, 2014)

Ng, E.S.W., Schweitzer, L., Lyons, S.T. (2010). New Generation, Great Expectations: A Field Study of the Millennial Generation. Journal of Business \& Psychology, Jun2010, Vol. 25 Issue 2, pp.

Pańków, M. (2012), Młodzi na rynku pracy. Raport z badania, Instytut Spraw Publicznych, Warszawa. [Online] Available: https://portal.uw.edu.pl/documents/5800711/331c4179-6e21-441f-86b0-34f044541ad2 (July 2, 2014)

Shragay, D., Tziner, A. (2011). The Generational Effect on the Relationship between Job Involvement, Work Satisfaction, and Organizational Citizenship Behavior, Revista de Psicología del Trabajo y de las Organizaciones Vol. 27, No 2, pp.143-157.

Smolbik-Jęczmień, A. (2013). Podejście do pracy i kariery zawodowej wśród przedstawicieli generacji X i Y - podobieństwa i różnice, Nauki o zarządzaniu nr 1, Publishing Uniwersytetu Ekonomicznego we Wrocławiu, Wrocław, pp. 89-98.

Stachowska, S. (2012). Oczekiwania przedstawicieli pokolenia Y wobec pracy i pracodawcy, Zarządzanie zasobami ludzkimi Nr 2, pp. 33-56.

Van den Bergh, J., Behrer, M. (2011). How Cool Brands Stay Hot: Branding to Generation Y, Wyd. Kogan Page.

Vinke J., Loredana, O., Nicolae, B. (2012). Gyroscopic management and generation Y. Annals of the University of Oradea, Economic Science Series, Vol. 21 Issue 2, pp. 750-755. 